\title{
Willingness to Join Community-Based Health Insurance and Factors Affect It Among Households of Selected Districts of West Shoa Zone, Ethiopia: A Community Based Cross Sectional Study
}

\author{
Mulugeta Mekuria [PI] Tsegaye Benti Eshetu E. Chaka \\ Ambo University, college of Medical and health science, department of Public health
}

\begin{abstract}
Back ground: CBHI is a kind of insurance for informal sectors through which the members contribute some amount of money to protect themselves against the high costs of seeking medical care and treatment for illness. The catastrophic nature of health care financing mechanism for the poor and often rural population has been a source of concern in the low and middle income countries . The aim of this study was to assess the household's willingness to join CBHI and factors affecting households to join community based health insurance. .Methodology: A community based cross sectional study was conducted in randomly selected districts of West Shoa Zone from January 25 to February 20, 2016. A sample of 292 head of the house holds were selected using simple random sampling technique from which data were collected by trained data collectors using a pretested structured questionnaire. The collected data were entered into SPSS version 20 for analysis .Descriptive statistics and bivariate and multiple logistic regression analyses were performed. Result: All of the 292 sampled head of the households participated in the study making the response rate of $100 \%$. About $71 \%$ of the respondents were willing to join the scheme. In multivariate logistic regression analyses, age of the head of the house holds, head of the household, the household's family size and having a person age 65 and above in the family, presence of chronic illness among the house holds, households concern for covering the health care cost and means of getting money for health care payment were found to be the predictors of the households' WTJ the CBHIs .Conclusion: In the study the households willingness to join community based health insurance was considered to be high. Therefore, scaling the scheme will be beneficial in the study areas.
\end{abstract}

Keywords: Community based health insurance, Willingness to join, West Shoa Zone, Ethiopia

DOI: $10.7176 / \mathrm{JHMN} / 65-03$

Publication date: August $31^{\text {st }} 2019$

\section{Back ground}

Community based health insurance is the kind of insurance for informal sectors through which members contribute some amount of money to protect themselves against the high cost of seeking medical care and treatment for illness $[1,2]$. It is based on the premise of risk-pooling and reducing out-of-pocket expenses for health care services [3, 4]. Operating by risk-pooling, they are financed through regular premiums and tailored to meet the needs of poorer people such as informal sector workers who would otherwise not be able to take out health insurance $[5,6]$. Even though, it is one of the recommended financing mechanisms in the African region [7], African governments focus on direct on out of payments [8].

Many low and middle-income countries (LMICs) are facing the challenge of raising sufficient funds to finance health services in an equitable way [9]. In fact, in these countries out-of-pocket payments remain the main method of paying for health care. This mode of payment limits access to quality healthcare [10,11] and can lead to the entire household becoming impoverished [12].

Since the mid-90s, CBHI schemes have been growing in number in Sub-Saharan Africa and other regions of the world [13].,The number of Community based health insurance schemes grew from 76 in 1997 to more than 800 by 2004 [14], and it is now part of the national health financing strategy in Benin, Ghana, Rwanda, Senegal and Tanzania [15-17].

In many LMICs direct out-of-pocket payments dominate healthcare financing [18]. It is routine for more than $2 \%$ of the population of the low income countries to suffer from health care financial catastrophe defined as having to spend over $40 \%$ the income after food on care[19] . In sub- Saharan African out of pocket expenditure constitutes approximately $40 \%$ of the total health expenditure, imposing financial burdens and limiting access to health care $[19,20]$.

Since such direct out -of- pocket payments are inequitable and inefficient in financing healthcare services [21], in the late 1990s there was a move away from out- of- pocket expenditure on health care to community based health insurance in most developing countries[22]. This is because they are accounting for a higher proportion of poorer households' income compared to richer households [9]. Thus, many households in LMICs lack adequate financial protection; households face financial catastrophe and impoverishing effects of paying for health services out-of-pocket [23]. In fact, annual estimates show that about 44 million households face catastrophic expenditure globally while about 25 million households are impoverished because of direct healthcare 
payments. Over $90 \%$ of these occur in LMICs including Ethiopia [24]. In response to adverse effects of direct out-of-pocket payments, the World Health Organization (WHO) is encouraging countries to move towards universal health coverage (UHC). This means that everyone should have access to needed healthcare services that are effective and of acceptable quality, and no one should risk financial ruin as a result of this. This is corroborated by evidence from many LMICs showing that health sector reforms in the form of adequate insurance or prepayment schemes contribute to increasing financial protection $[21,25]$

Although CBHI schemes are criticized for the limited extent of resource generation and pooling, they have been shown to facilitate and improve access to healthcare services, especially among children and pregnant women $[26,27]$ and addresses, to some extent, healthcare challenges faced specifically by the rural poor and informal workers. However, enrolment to CBHI schemes remains a challenge mainly because of their voluntary nature [28]. In Africa only 2 million people out of an estimated population of 900 million people are enrolled in a CBHI scheme. This amounts to just $0.2 \%$ of the catchment population [29].

Ethiopia endorsed health care financing strategies 1990, that initiates a wide range of reforms and which recognizes multiple financing sources including community based health insurance. The CBHI strategy in Ethiopia can be said to have taken birth from an ancient Ethiopian traditional practice known as the Idir. Over the years, this traditional financial institution has translated into a healthcare insurance scheme that requires the contribution of funds amongst community members to help cater to health care needs whenever a member is sick[30].

While the Idir practice caters to unforeseen emergencies such as deaths, CBHI in Ethiopia attempts to prevent these expected emergencies by converting these same finances to a life saver rather than funeral fund. Accordingly, the initiative was launched as the first of its kind in 2011 across 13 districts with 1.45 million people within the four main regions of the country: Amhara, SNNPR, Tigray and Oromia as pilot implementation. Three pilot Districts were chosen from each of the first districts while four districts were chosen from Oromia. [30,31].

In Ethiopia $38.5 \%$ of the total health expenditure was covered through out of pocket charges which is higher than that of other African countries which was 30.6\% in 2008[32]. Therefore moving away from out of pocket charge for health care at a time of use is important step towards averting the financial hardship associated with paying for health service. To this end Ethiopia planned to reduce out of pocket health expenditure to less than $15 \%$ and to increase proportion of people enrolled in health insurance from 1 percent to 50 percent at the end of 2014/15[33]. However the enrollment is low in many places where CBHI are established. The review of CBHI found that $50 \%$ them had less than 500 members while only $2 \%$ of the schemes had more than 100,000 members [34].

Currently, the Ethiopian federal ministry of health, have taken the initiative to reach at least $80 \%$ of the households in $80 \%$ of the districts should enrolled in community health insurance by 2020[33].There fore this study aims to provide insight about the factors that influence the house holds willingness to join CBHI in the study area.

\section{Methods}

Study area and period

A community based cross-sectional study was conducted among the households in the randomly selected districts of West Shoa Zone, from January 25 to February 20, 2016. West Shoa Zone is one of the eighteen zones of Oromia regional state which is located in western direction from Addis Abeba. The zone has 22 rural districts and one urban administrative which are divided into 529 rural kebeles and 43 urban kebeles with the total population of 2,447,432 [34]. "Kebele" is the lowest administrative unit in Ethiopia which comprises at least 1000 households or population of 5000 people. Out of the total districts in the zone, four of them (Bako Tibe, Ada Barga, Gindeberet and Jibat) were selected as the pilot implementation area for the community-based health insurance at the time of data collection. In these districts there were 109,393 households, of which 10,549 heads of the households are governmental employees, and 99, 346 head are non employees. . A sample size of 292 was calculated by a single proportion formula, taking $\mathrm{P}=77.8 \%$ of willingness to join community based health insurance among rural households of in Debub Bench District, Southwest Ethiopia [38] , 95\% confidence interval, $\alpha=0.05$ margin of error, $d=5 \%$ degree of precision and considering $10 \%$ non- response rate

Among the four districts which were implementing community based health insurance two districts were selected by lottery methods. In these selected districts there are 54 rural kebles and 2 urban adminstratives. From 54 rural kebeles , 16 were selected randomly. The participating households were allocated to these 16 kebeles proportionate to the sizes of the kebeles. List of households in each kebele was obtained from health extension workers, and simple random sampling technique was used to selected the households .

\section{Data Collection and instrument}

Face-to-face interview was conducted using structured and pre-tested questionnaires. The questionnaire were adopted from the relevant literature and includes socio- demographic characteristics, health and health related 
variables and willingness to participate in community based health insurance schemes. Both data collectors and supervisors were given 3-days training on the objectives, method of data collection, and data collection instruments. The collected data were entered into SPSS version 21.0 for analysis .Descriptive statistics, bivariate and multiple logistic regression analyses were performed. P- values less than 0.05 and $95 \%$ confidence intervals were used to determine associations between dependent and independent variables.

\section{Result and discussion \\ Result}

All of 292 sampled households participated in the study making the response rate of $100 \%$. The median age of the respondents was 36.4 ranging from 18 to 60 years with standard deviation of 13.1 years. One hundred eight seven $(64.0 \%)$ of the respondents were males, 141(48.3\%) were orthodox christian and $268(91.8 \%)$ were married. The median number of household family size was 5.4 with range of 2-9 and 1.9 standard deviation. Just over half, $154(52.7 \%)$ of the study participants had less than five family size and $53(18.2 \%)$ of the respondents were reported that they had person 65 years and above in the family. One hundred sixty nine $(57.9 \%)$ of the participants attended up to primary education level and 198(67.8\%) of them were farmer in occupation (Table 1)

Table 1: Socio-demographic characteristics of study participants in selected District of West Shoa Zone, Ethiopia, 2016

\begin{tabular}{|c|c|c|}
\hline Variable & Frequency $(\mathbf{N})$ & Percentage (\%) \\
\hline \multicolumn{3}{|l|}{ Sex } \\
\hline Male & 187 & 64.0 \\
\hline Female & 105 & 36.0 \\
\hline \multicolumn{3}{|l|}{ Mean age } \\
\hline Less and equal to mean age & 168 & 57.5 \\
\hline Above mean age & 124 & 42.5 \\
\hline \multicolumn{3}{|l|}{ Religion } \\
\hline Protestant & 112 & 38.4 \\
\hline Orthodox & 141 & 48.3 \\
\hline Muslim & 12 & 4.1 \\
\hline Wakeffata & 27 & 9.2 \\
\hline \multicolumn{3}{|l|}{ Marital status } \\
\hline Married & 268 & 91.8 \\
\hline Widowed & 24 & 8.2 \\
\hline \multicolumn{3}{|l|}{ Family size } \\
\hline$=<5$ & 154 & 52.7 \\
\hline$>5$ & 138 & 47.3 \\
\hline \multicolumn{3}{|c|}{ A person age 65 years and above in the households } \\
\hline Yes & 53 & 18.2 \\
\hline No & 239 & 81.8 \\
\hline \multicolumn{3}{|l|}{ Educational level } \\
\hline Cannot read and write & 78 & 26.7 \\
\hline Can read and write & 30 & 10.3 \\
\hline Grade 1-8 & 169 & 57.9 \\
\hline Secondary school and above & 15 & 5.1 \\
\hline \multicolumn{3}{|l|}{ Occupation of the respondents } \\
\hline Farmer & 198 & 67.8 \\
\hline Merchant & 94 & 32.2 \\
\hline Total & 292 & 100 \\
\hline
\end{tabular}

Health and health related situation

With respect to health and health related situations, $70(24.0 \%)$ of the respondents had at least one member with chronic disease or disability; and 129 (44.2\%) of the households had at least one member who had encountered illnesses 3 months prior to data collection. Among the ill, 98 (33.6\%) of them had got treatment for the illnesses they experienced. The remaining $31(10.6 \%)$ did not get treatment because of lack of enough money. Of 98(33.6\%) individuals who got treatment, the majority $29(29.6 \%)$ preferred to go public hospitals. They preferred the specified institutions because of its physical accessibility, $48(48.0 \%)$, not too crowded $23(23.3 \%)$, not expensive services $15(15.3 \%)$,and effective service $13(13.4 \%)$. Seventy six $(77.6 \%)$ of the households covered the medical expenses by themselves. One hundred eight $(55.7 \%)$ of these households reported that it was difficult to cover payments for treatments. As a result, $42(26.6 \%)$ of them were assisted by relatives ; $23(14.6 \%)$ drew from their savings, and $80(50.6 \%)$ borrowed from someone to cover the medical costs. The remaining $13(8.2 \%)$ had to sell 
capital assets such as cows, land, teff etc, to cover the payments for treatment. Of 292 respondents, $189(64.7 \%)$ reported that they had borrowed money for covering health care expenses within one year before the data were collected. The median amount that these households borrowed was 505 ETB (21.5USD), ranging 50-3000 ETB (2.1 -127.7USD) (Table 2).

Table 2:- Health and health related situations of the respondents in selected Districts of West Shoa Zone, Ethiopia, 2016

\begin{tabular}{|c|c|c|}
\hline Variable & Frequency $(\mathbf{N})$ & Percentage $(\%)$ \\
\hline \multicolumn{3}{|l|}{ Chronic illness } \\
\hline Yes & 70 & 24.0 \\
\hline No & 222 & 76.0 \\
\hline \multicolumn{3}{|l|}{ Illness encountered in the last 3 months } \\
\hline ( & 129 & 44.2 \\
\hline No & 163 & 55.8 \\
\hline \multicolumn{3}{|l|}{ Seek medical treatment } \\
\hline Yes & 98 & 33.6 \\
\hline No & 31 & 10.6 \\
\hline \multicolumn{3}{|l|}{ Place of treatment } \\
\hline Private health facility & 15 & 15.3 \\
\hline Public health facility & 17 & 17.3 \\
\hline Public hospitals & 29 & 29.6 \\
\hline Others & 37 & 37.8 \\
\hline \multicolumn{3}{|l|}{ Why you go there } \\
\hline Physical accessibility & 47 & 48.0 \\
\hline Not expensive & 15 & 15.3 \\
\hline Not crowded & 23 & 23.5 \\
\hline Effective & 13 & 13.3 \\
\hline \multicolumn{3}{|l|}{ Reason for not getting treatment } \\
\hline No enough money & 17 & 54.8 \\
\hline Other(self limiting, busy with work ) & 14 & 45.2 \\
\hline \multicolumn{3}{|l|}{ Coverage of the health care cost } \\
\hline Self & 76 & 77.4 \\
\hline Other & 22 & 22.4 \\
\hline \multicolumn{3}{|c|}{ Concern of the households for covering the health care cost } \\
\hline Very difficult & 55 & 28.4 \\
\hline Difficult & 108 & 55.7 \\
\hline Not difficult & 31 & 28.9 \\
\hline \multicolumn{3}{|c|}{ Means of getting money for health care payment } \\
\hline Borrowed from some one & 80 & 50.6 \\
\hline Assisted by relatives & 42 & 26.6 \\
\hline Sell capital assets (land, cow ,teff, etc ) & 13 & 8.2 \\
\hline With draw from the bank & 23 & 14.6 \\
\hline \multicolumn{3}{|c|}{ Borrowed money for medical cost within the last one year } \\
\hline Yes & 189 & 64.7 \\
\hline No & 103 & 35.3 \\
\hline Total & 292 & 100 \\
\hline
\end{tabular}

Willingness to join community based health insurance

Among the study participants, 207 (70.9\%) were willing to join the proposed community based health insurance. The reason mentioned by the study participants to join community based health insurance were $97(46.9 \%)$ to get free access to health care , 45(21.7\%) to help other family members, and $65(31.4 \%)$ face health problems frequently. Among 85( 29.1\%) of the study participants who were not willing to join the scheme ,23(27.1\%) of them were mention health insurance is confusing , 15(17.6\%) were due to lack of government trust and $17(17.6 \%$ ) do not need health insurance at all (Table 3 ). 
Table 3: House hold willingness to join community based health insurance, reasons for and not willing to join the scheme in selected District of West Shoa Zone, Ethiopia, 2016

\begin{tabular}{|c|c|c|}
\hline Variable & Frequency $(\mathbf{N})$ & Percentage (\%) \\
\hline \multicolumn{3}{|l|}{ Willingness to join CBHI scheme $(n=292)$} \\
\hline Yes & 207 & 70.9 \\
\hline No & 85 & 29.1 \\
\hline \multicolumn{3}{|l|}{ Reason for willing to join $\mathrm{CBHI}$ scheme(n=207) } \\
\hline It provides free access to medical care & 97 & 46.9 \\
\hline To help other & 45 & 21.7 \\
\hline Facing health problems frequently & 65 & 31.4 \\
\hline \multicolumn{3}{|l|}{ Reason for not join CBHI scheme $(n=85)$} \\
\hline I do not have enough money to pay & 15 & 17.6 \\
\hline The proposed money by government is high & 10 & 11.8 \\
\hline I do not need health insurance & 8 & 9.4 \\
\hline Out of pocket payment is better & 5 & 5.9 \\
\hline $\begin{array}{l}\text { Lack of Trust government in government } \\
\text { program }\end{array}$ & 15 & 17.6 \\
\hline Lack of functional Health facilities in my village & 9 & 10.6 \\
\hline Health insurance is confusing scheme & 23 & 27.1 \\
\hline
\end{tabular}

Factors associated with community based health insurance

Socio-demographic factors

Bivariate analysis was done crudely in order to identify the socio-demographic variables that fit multiple logistic regression models.. Accordingly, head of the households age (Crude OR $=1.023,95 \%$ of $\mathrm{CI}=$.) $=1.002-1.045)$, households relationship (Crude $\mathrm{OR}=2.321,95 \%$ of $\mathrm{CI}=1.246-4.323$ ) ,being protestant religion followers (Crude OR $=.483,95 \%$ of $\mathrm{CI}=.273-.853$ ), and wakeffata(one of the religion type in Ethiopia) (Crude $\mathrm{OR}=3.895,95 \%$ of $\mathrm{CI}=1.102-13.763)$ an widowed in marital status (Crude $\mathrm{OR}=2.671,95 \% \mathrm{CI}=1.148-6.213$ ) were socio-demographic variables that showed statistically significant association withhouse holds willingness to join community based health insurance

In addition, households who had person age of 65years and above in their family(Crude OR=7.309, 95\% $\mathrm{CI}=3.167-8.1570$ ) who cannot read and write( Crude $\mathrm{OR}=35.75,95 \% \mathrm{CI}=11.519-110.955)$, can only read and write (Crude $\mathrm{OR}=2.912,95 \% \mathrm{CI}=1.557-5.447)$ who attended secondary school and above in education level and who were marchant by occupation (Crude $\mathrm{OR}=3.263,95 \%$ of $\mathrm{CI}=1.203-11.174$ ) were showed statistically significant association with willingness to join community based health insurance while sex of the study participants did not show significant association. Among the socio-demographic variables which showed association, except the protestant religion followers which showed negative association, the others variables showed positively associatiated with willingness to join CBHI(Table 4). 
Table 4: Binary logistic regression analysis of socio-demographic characteristics with willingness to join CBHI in selected Districts of West Shoa Zone, Ethiopia, 2016

\begin{tabular}{|c|c|c|c|c|c|}
\hline \multirow[t]{2}{*}{ Variable } & \multirow[t]{2}{*}{$\begin{array}{l}\text { Frequency } \\
\text { (N) }\end{array}$} & \multicolumn{2}{|l|}{ WTJ } & \multirow[t]{2}{*}{$\begin{array}{l}\text { P- } \\
\text { value }\end{array}$} & \multirow[t]{2}{*}{ Crude OR , 95\% CI } \\
\hline & & Yes $(\%)$ & No $(\%)$ & & \\
\hline Age & & $207(70.9)$ & $85(29.1)$ & .031 & $1.023(1.002-1.045)$ \\
\hline Sex & & 85 & & & \\
\hline Male & $187(64.0)$ & $130(44.5)$ & $57(19.5)$ & & $1 *$ \\
\hline Female & $105(36.0)$ & $77(26.4)$ & $28(9.6)$ & 514 & $1.190(.706-2.005)$ \\
\hline \multicolumn{6}{|l|}{ Relation ship } \\
\hline Head & $253(86.6)$ & $196(67.1)$ & $57(19.5)$ & & $1 *$ \\
\hline Spouse & $39(13.4)$ & $11(3.8)$ & $28(9.6)$ & .008 & $2.321(1.246-4.323)$ \\
\hline \multicolumn{6}{|l|}{ Religion } \\
\hline Orthodox & $141(48.3)$ & $112(38.4)$ & $29(9.90)$ & & \\
\hline Protestant & $112(38.4)$ & $69(23.6)$ & $43(14.7)$ & .012 & $.483(.273-.853)$ \\
\hline Wakeffata & $27(9.2)$ & $21(7.2)$ & $6(2.1)$ & .035 & $3.895(1.102-13.763)$ \\
\hline Muslim & $12(4.1)$ & $5(1.7)$ & $7(2.4)$ & .507 & $1.339(.566-3.169)$ \\
\hline \multicolumn{6}{|l|}{ Marital status } \\
\hline Married & $268(91.8)$ & $195(66.8)$ & $73(25.0)$ & & $1 *$ \\
\hline Widowed & $24(8.2)$ & $12(4.1)$ & $12(4.1)$ & .023 & $2.671(1.148-6.213)$ \\
\hline Family size & & & & .022 & $.847(.735-.976)$ \\
\hline \multicolumn{6}{|c|}{$\begin{array}{l}\text { A person with age } 65 \text { years } \& \\
\text { above }\end{array}$} \\
\hline No & $239(81.8)$ & $195(66.8)$ & $44(15.1)$ & & $1 *$ \\
\hline Yes & $53(18.2)$ & $12(4.1)$ & $41(14.0)$ & .000 & $.309(.167-.570)$ \\
\hline \multicolumn{6}{|l|}{ Educational level } \\
\hline Grade 1-8 & $169(57.9)$ & $126(43.2)$ & $43(14.7)$ & & $1 *$ \\
\hline Cannot read and write & $78(26.7)$ & $72(24.7)$ & $692.1)$ & .000 & $\begin{array}{l}35.750(11.519- \\
110.955)\end{array}$ \\
\hline Can read and write & $30(10.3)$ & $4(1.4)$ & $26(8.9)$ & .001 & $2.912(1.557-5.447)$ \\
\hline Secondary school and above & $15(5.1)$ & $5(1.7)$ & $10(3.4)$ & .022 & $3.667(1.203-11.174)$ \\
\hline \multicolumn{6}{|l|}{ Occupation of the house hold } \\
\hline Farmer & $198(67.8)$ & $188(64.4)$ & $10(3.4)$ & & \\
\hline Merchant & $94(32.2)$ & $19(6.5)$ & $75(25.7)$ & .000 & $3.628(2.129-6.182)$ \\
\hline
\end{tabular}

Health and health related factors

Among health and health related variables; the presence of chronic illness in the households(Crude OR $=0.422$, $95 \%$ of $\mathrm{CI}=.0 .214-0.835$ ), illness encountered in the last three months(Crude OR $=0.413,95 \%$ of $\mathrm{CI}=.0 .240$ 0.708 ), the reason for choosing health facilties(not crowded) (Crude OR $=3.000,95 \%$ of CI=.1.039-8.666), , borrowing money from someone for health care payment(Crude OR $=28.333,95 \%$ of $\mathrm{CI}=.10 .243-78.372$ ), and, borrowing money for medical cost within the last one year(Crude OR $=1.522,95 \%$ of CI=.1.285-1.958), showed statistically significant association with willingness to join community based health insurance on bivariate logistic regression analysis (Table 5).

\begin{tabular}{llllll}
\hline Merchant & $94(32.2)$ & $19(6.5)$ & $75(25.7)$ & .000 & $3.628(2.129-6.182)$ \\
\hline
\end{tabular}


Table 5. Binary logistic regression analysis of health and health related characteristics with willingness to join CBHI in selected Districts of West Shoa zone, Ethiopia, 2016

\begin{tabular}{|c|c|c|c|c|c|}
\hline \multirow[t]{2}{*}{ Variable } & \multirow{2}{*}{$\begin{array}{l}\text { Frequency } \\
(\%)\end{array}$} & \multicolumn{2}{|l|}{ WTJ } & \multirow[b]{2}{*}{ P-value } & \multirow[b]{2}{*}{ Crud OR,95 CI } \\
\hline & & Yes & No & & \\
\hline \multicolumn{6}{|l|}{ Chronic illness } \\
\hline No & $222(76.0)$ & $149(51.0)$ & $73(25.0)$ & & $1 *$ \\
\hline Yes & $70(24.0)$ & $58(19.9)$ & $12(4.1)$ & .013 & $.422(.214-.835)$ \\
\hline \multicolumn{6}{|l|}{$\begin{array}{l}\text { Illness encountered in the last } 3 \\
\text { months }\end{array}$} \\
\hline Yes & $163(55.8)$ & $103(35.3)$ & $60(20.5)$ & & $1 *$ \\
\hline No & $129(44.2)$ & $104(35.6)$ & $25(8.6)$ & .001 & $.413(.240-.708)$ \\
\hline \multicolumn{6}{|l|}{ Seek medical treatment } \\
\hline Yes & $98(33.6)$ & $80(62.0)$ & $18(14.0)$ & & \\
\hline No & $31(10.6)$ & $24(18.6)$ & $7(5.4)$ & .606 & $1.296(.484-3.471)$ \\
\hline \multicolumn{6}{|l|}{ Place of treatment } \\
\hline Others & $37(37.8)$ & $34(34.7)$ & $3(3.1)$ & & $1 *$ \\
\hline Public hospital & $29(29.6)$ & $25(25.5)$ & $4(4.1)$ & .907 & $1.091(.252-4.714)$ \\
\hline Public health center & $17(17.3)$ & $11(11.2)$ & $6(6.1)$ & .138 & $.320(.071-1.442)$ \\
\hline Private health facility & $15(15.3)$ & $10(10.2)$ & $5(5.1)$ & .103 & $.176(.036-1.870)$ \\
\hline \multicolumn{6}{|l|}{ Who paid for you } \\
\hline Self & $76(76.6))$ & $40(40.8)$ & $36(36.7)$ & & $1 *$ \\
\hline Other & $22(22.4)$ & $12(12.2)$ & $10(10.2)$ & .874 & $.926(.357-2.400)$ \\
\hline \multicolumn{6}{|l|}{ Why you go there } \\
\hline Physical accessibility & $47(48.0)$ & $36(36.7)$ & 11(11.3) & & $1^{*}$ \\
\hline Not crowded & $23(23.5)$ & $12(12.2)$ & $11(11.3)$ & .042 & $3.000(1.039-8.666)$ \\
\hline Not expensive & $15(15.3)$ & $9(9.2)$ & $6(6.1)$ & .215 & $2.182(.635-7.495)$ \\
\hline Effective & $13(13.3)$ & $7(7.1)$ & $6(6.1)$ & .115 & $2.805(.778-10.115)$ \\
\hline \multicolumn{6}{|l|}{ Reason for not treated } \\
\hline No enough money & $17(54.8)$ & $14(45.2)$ & $3(9.7)$ & & $1^{*}$ \\
\hline Other (family, etc.) & $14(45.2)$ & $12(38.7)$ & $2(6.5)$ & .874 & $.926(.357-2.400)$ \\
\hline \multicolumn{6}{|l|}{$\begin{array}{l}\text { Concern of the households for } \\
\text { covering the health care cost }\end{array}$} \\
\hline Very difficult & $55(28.4)$ & $60(30.9)$ & $48(24.7)$ & & $1 *$ \\
\hline Difficult & $108(55.7)$ & $21(10.8)$ & $34(17$. & .037 & $2.024(1.043-3.929)$ \\
\hline Not difficult & $31(28.9)$ & $28(14.4)$ & $3(1.5)$ & .002 & $.134(.038-.467)$ \\
\hline \multicolumn{6}{|l|}{$\begin{array}{l}\text { Means of getting money for } \\
\text { health care payment }\end{array}$} \\
\hline Sell capital asset & $80(50.6)$ & $68(43.0)$ & $12(7.6)$ & & \\
\hline Borrowed from some one & $42(26.6)$ & $7(4.4)$ & $35(22.2)$ & .000 & $28.333(10.243-78.372)$ \\
\hline $\begin{array}{l}\text { With draw from the bank } \\
\text { account }\end{array}$ & $23(14.6)$ & $1(0.6)$ & $22(13.9)$ & .971 & $1.030(.203-5.242)$ \\
\hline Assisted by relatives & $13(8.2)$ & $11(7.0)$ & $2(1.3)$ & .000 & $12.667(13.85-15.329)$ \\
\hline \multicolumn{6}{|l|}{$\begin{array}{l}\text { Borrowed money for medical } \\
\text { cost within the last one year }\end{array}$} \\
\hline Yes & $208(71.2)$ & $140(47.9)$ & $68(23.3)$ & & $1 *$ \\
\hline No & $84(28.8($ & $67(22.9)$ & $17(5.8)$ & .003 & $1.522(1.285-1.958)$ \\
\hline
\end{tabular}

Predictors of willingness to join community based health insurance

All socio demographic and health related variables that showed significant association with willingness to join community based health insurance in bivariate logistic regression were entered into multiple logistic regression models to control potential confounders. Accordingly, , most of the socio-demographic variables which includes head of the households age (Adjusted OR: 1.020, 95\% CI of 1.001, 1.034), female as head of the households (Adjusted $\mathrm{OR}=3.739,95 \% \mathrm{CI}=1.666-8.391$ ), the households family size(Adjusted OR: $2.817,95 \% \mathrm{CI}=1.707$, 2.946), households who had person age of 65years and above in their family(Adjusted OR: $6.562,95 \% \mathrm{CI}=$ $2.899,14.856)$, were significantly associated with willingness to join CBHIs.

From the health and health related variables households who had a person with chronic illness or disability [Adjusted OR $=1.290 \quad 95 \% \mathrm{CI}=1.092-1.719$ ), borrowing money from someone for health care payment(Adjusted $\mathrm{OR}=1.656,95 \%$ of $\mathrm{CI}=.1 .760-3.606$ ), and households who did not get difficult for covering the health care cost(Adjusted $\mathrm{OR}=0.061,95 \%$ of $\mathrm{CI}=0.017-0.222$ ) were found to be significant predictors for the households' WTJ the community based health insurance. 
Table -6. Factors associated with willingness to join community based health insurances in selected Districts of West Shoa Zone, Ethiopia, 2016

\begin{tabular}{|c|c|c|c|c|c|c|}
\hline \multirow[t]{2}{*}{ Variable } & \multirow[t]{3}{*}{ Frequency (N) } & \multicolumn{2}{|l|}{ WTJ } & \multirow[t]{2}{*}{ Crude OR, $95 \%$ CI } & Adjusted OR, 95\% CI & \multirow[b]{3}{*}{0.045} \\
\hline & & Yes (\%) & No(\%) & & & \\
\hline Age & & $207(70.9)$ & $85(29.1)$ & $1.023(1.002-1.045)$ & $1.020(1.001-1.034)$ & \\
\hline \multicolumn{7}{|l|}{ Relation ship } \\
\hline Head & 253(86.6) & 196(67.1) & $57(19.5)$ & $1^{*}$ & & \\
\hline Spouse & $39(13.4)$ & $11(3.8)$ & $28(9.6)$ & $2.321(1.246-4.323)$ & $3.739(1.666-8.391)$ & .001 \\
\hline \multicolumn{7}{|l|}{ Religion } \\
\hline Orthodox & $141(48.3)$ & $112(38.4)$ & $29(9.90)$ & & & \\
\hline Protestant & $112(38.4)$ & $69(23.6)$ & $43(14.7)$ & $.483(.273-.853)$ & $.695(.313-1.543)$ & .372 \\
\hline Wakeffata & $27(9.2)$ & $21(7.2)$ & $6(2.1)$ & $3.895(1.102-13.763)$ & $2.502(.845-.7 .410)$ & .098 \\
\hline Muslim & $12(4.1)$ & $5(1.7)$ & $7(2.4)$ & $1.339(.566-3.169)$ & $2.196(.598-8.071)$ & .236 \\
\hline \multicolumn{7}{|l|}{ Marital status } \\
\hline Married & $268(91.8)$ & 195(66.8) & $73(25.0)$ & $1^{*}$ & $1^{*}$ & \\
\hline Widowed & $24(8.2)$ & $12(4.1)$ & $12(4.1)$ & $2.671(1.148-6.213)$ & $1.871(0.848-3.313)$ & 0.089 \\
\hline Family size & & & & $.847(.735-.976)$ & $.817(.705-.946)$ & .007 \\
\hline \multicolumn{7}{|l|}{$\begin{array}{l}\text { Age } 65 \text { years \& } \\
\text { above }\end{array}$} \\
\hline No & 239(81.8) & 195(66.8) & $44(15.1)$ & $1^{*}$ & & \\
\hline Yes & $53(18.2)$ & $12(4.1)$ & $41(14.0)$ & $.309(.167-.570)$ & $6.562(2.899-14.856)$ & .000 \\
\hline \multicolumn{7}{|l|}{ Education level } \\
\hline Grade 1-8 & 169(57.9) & $126(43.2)$ & $43(14.7)$ & $1^{*}$ & $1^{*}$ & \\
\hline $\begin{array}{l}\text { Cannot read and } \\
\text { write }\end{array}$ & $78(26.7)$ & $72(24.7)$ & $69(2.1)$ & $35.750(11.519-110.955)$ & $3.50(1.119-11.095)$ & .047 \\
\hline Can read and write & $30(10.3)$ & $4(1.4)$ & $26(8.9)$ & $2.912(1.557-5.447)$ & $2.912(1.557-5.447)$ & .032 \\
\hline $\begin{array}{l}\text { Secondary } \\
\text { and above }\end{array}$ & $15(5.1)$ & $5(1.7)$ & $10(3.4)$ & $3.667(1.203-11.174)$ & $3.667(1.203-11.174)$ & 0.012 \\
\hline \multicolumn{7}{|l|}{$\begin{array}{l}\begin{array}{l}\text { Occupation of the } \\
\text { house hold }\end{array} \\
\text { h }\end{array}$} \\
\hline Farmer & $198(67.8)$ & 188(64.4) & $10(3.4)$ & 1 & $1^{*}$ & \\
\hline Merchant & $94(32.2)$ & $19(6.5)$ & $75(25.7)$ & $3.628(2.129-6.182)$ & $.423(.273-1.276)$ & .735 \\
\hline \multicolumn{7}{|l|}{ Chronic illness } \\
\hline No & $222(76.0)$ & $149(51.0)$ & $73(25.0)$ & $1^{*}$ & & \\
\hline Yes & $70(24.0)$ & $58(19.9)$ & $12(4.1)$ & $.422(.214-.835)$ & $.290(.092-.917)$ & .035 \\
\hline \multicolumn{7}{|l|}{$\begin{array}{l}\text { Illness encountered in } \\
\text { the last three months }\end{array}$} \\
\hline Yes & $163(55.8)$ & 103(35.3) & $60(20.5)$ & $1 *$ & & \\
\hline No & $129(44.2)$ & $104(35.6)$ & $25(8.6)$ & $.413(.240-.708)$ & $.294(.216-1.159)$ & .162 \\
\hline \multicolumn{7}{|l|}{ Why you go there } \\
\hline Physical accessibility & $47(48.0)$ & $36(36.7)$ & $11(11.3)$ & $1^{*}$ & & \\
\hline Not crowded & $23(23.5)$ & $12(12.2)$ & $11(11.3)$ & $3.000(1.039-8.666)$ & $1.605(.496-5.189)$ & .430 \\
\hline Not expensive & $15(15.3)$ & $9(9.2)$ & $6(6.1)$ & $2.182(.635-7.495)$ & $.701(.161-3.053)$ & .636 \\
\hline Effective & $13(13.3)$ & $7(7.1)$ & $6(6.1)$ & $2.805(.778-10.115)$ & $.878(.158-4.873)$ & .882 \\
\hline \multicolumn{7}{|l|}{$\begin{array}{l}\text { Means of getting } \\
\text { money for health } \\
\text { care payment }\end{array}$} \\
\hline Sell capital asset & $80(50.6)$ & $68(43.0)$ & $12(7.6)$ & & & \\
\hline $\begin{array}{l}\text { Borrowed from some } \\
\text { one }\end{array}$ & $42(26.6)$ & $7(4.4)$ & $35(22.2)$ & $28.333(10.243-78.372)$ & $1.656(1.760-3.606)$ & .04 \\
\hline $\begin{array}{l}\text { With draw from the } \\
\text { bank account }\end{array}$ & 23(14.6) & $1(0.6)$ & $22(13.9)$ & $1.030(.203-5.242)$ & $.529(.133-2.110)$ & .367 \\
\hline assisted by relatives & $13(8.2)$ & $11(7.0)$ & $2(1.3)$ & $12.667(13.85-15.329)$ & $1.045(.311-3.518)$ & .943 \\
\hline \multicolumn{7}{|l|}{$\begin{array}{lr}\text { Concern } & \text { of } \\
\text { households } & \text { for } \\
\text { covering the } & \text { health } \\
\text { care cost }\end{array}$} \\
\hline Very difficult & $55(28.4)$ & $60(30.9)$ & $48(24.7)$ & & & \\
\hline Difficult & $108(55.7)$ & $21(10.8)$ & $34(17$. & $2.024(1.043-3.929)$ & 1.799. (.829- 3.902) & .137 \\
\hline Not difficult & $31(28.9)$ & $28(14.4)$ & $3(1.5)$ & $.134(.038-.467)$ & $.061(.017-.222)$ & .000 \\
\hline \multicolumn{7}{|l|}{$\begin{array}{l}\text { Borrowed money for } \\
\text { medical cost within } \\
\text { the last one year }\end{array}$} \\
\hline Yes & $208(71.2)$ & $140(47.9)$ & $68(23.3)$ & $1^{*}$ & $1^{*}$ & \\
\hline No & $84(28.8($ & $67(22.9)$ & $17(5.8)$ & $1.522(1.285-2.9580)$ & $.551(.246-1.234)$ & .147 \\
\hline
\end{tabular}

\section{Discussion}

The finding of this study indicated that majority, $70.9 \%$ of the households were willing to join the community based health insurance which is almost similar to the study done in Ecuador which was 69\% [35] .However this figure is greater than the finding obtained from the study done in Edo state of Nigeria which was (60\%) [36].

However this figure was less than the finding obtained from the study done in the rural community of Fogera districts of Ethiopia, Debub Bench district of south west Ethiopia and Jima town in which the households willingness to the join the proposed community based health insurance scheme was $80 \%, 77.8$ and $76.5 \%$ respectively [37,38]. This disparity may be due to the commitment employed to give awareness about the community based health insurance for households in these study areas Obviously, local administrators commitment to implement the government policies in most aspects differ in different geographic regions and time. In addition the difference may due to the approach employed during data collection time . Particularly the Debub Bench district of South West Ethiopia and Jima town studies [37,38], data were collected after presenting the scenario of community based health insurance scheme for the respondents and after that the respondents were asked whether they were willing to join the scheme. This may simplifies understanding of the respondents on community based health insurance schemes which probably increases their willingness level to join the CMHI scheme

This study also showed that as the head of household's age was increases the houselds willing to join the 
CBHI was increased by 1.020 when compared to the younger the head of house hold (table 6). This finding is consistent with the finding obtained from the a systematic review and meta-analysis on what factors affect voluntary uptake of community based health insurance schemes in Low- and Middle-Income Countries[39].

Female as head of the household is another significant determinant of willingness to join CBHI. Unlike the findings from other similar studies $(37,39)$ this study revealed that female as being head of the house hold increases their willing to join community based health insurance schemes 3.739 more likely when compared to male as head of the households(Table-6).

This is a paradoxical result in which some of the African countries context men are presumed to be responsible for financial decisions within the households. Still this finding can be more justified as women are more proactive in engaging in the social security packages to protecting their families in most parts of the world. Another key factor that affected uptake of the CBHI scheme was the family size. The number of total family size had positive associations with the probability of WTJ the CBHIS. As the number of the household members increase, the likely hood of the house holdss willingness to join the community based health insurance increased by 2.817 times when compared to the households relatively smaller family sizes. This finding was supported with the study founding in Edo state of Nigeria, Ecuador and rural areas of Debub Bench Districts of south Ethiopia $(35,36,38)$. This positive association of large family size with willing to join community based health insurance could be as a result of the huge financial burden faced by households when they seek health care services. However, this finding was not consistent with other studies [40, 41].

The study also revealed that households who had person age of 65 years and above in their family showed 6.562 times more likely to join community based health insurance. This is probably the presence of elderly people in household triggers the households to decide to join the schemes as most of the time these old people consumption of health is very common. However studies in the Asian and Sub-Saharan[42,43]countries indicated a negative association between the two.

In addition, in this study the presence of chronic illnesses in households was 1.290 times more likely to join the CBHI than those who reported no chronic illnesses in the households. This is because households with more persons stand to gain more from joining the scheme than households with fewer sick person [48]. This is consistent with other studies $[46,47]$ which reported that the effect of chronic illnesses in the household on enrolment was a positive association between chronic illnesses in the household and enrolment in CBHI.

Households who get money for health care payment by means of borrowing money from someone for covering treatments were about 2.333 times more likely to join the scheme than those who soled capital asset for covering treatments (Table 6)

This is in line with a study done in Nigeria (35) and Debub Bench District of Southern Ethiopia (38). This is probable because anywhere in the world it is natural for people to aspire to solve the problem they encountered not happen again to them and to their relatives.

Concern of households for covering health care cost is also another factor for willingness to join joining CBHI. The study also showed that, households who have not difficult concern for covering healthcare cost at the time of illness were 0.061 less likely to join $\mathrm{CBHI}$ when compared to those who have difficult concern. This is might be due to households perception in which they think that the same situation will happen in their future life, if previously not get difficult to cover the health care cost at the time of illness.

\title{
Limitation of the Study
}

Since the study was conducted in similar population where already the community based health insurance was declared some households have information about the scheme. This may lead them to the information bias.In addition the study did not focus on factors like awareness, attitude towards risk/insurance etc which are the key areas where the implementers can directly play an important role and enable the individuals for an informed choices.

\section{Conclusion}

In this study the willingness of the households to join community based health insurance was $70.9 \%$ which indicated that the acceptance of the scheme was relatively high.. Thus implementation of the scheme was promising for the policy makers and local implementers of the schemes. Therefore scaling up of this scheme will be beneficial in the study areas in realization of the intended the health care financing initiation of government. as a means to providing access to health services .

\author{
List of abbreviations \\ CBHI: Community based health insurance \\ WTJ: Willingness to join \\ COR: Crude odd Ration \\ AOR: Adjusted odd Ratio
}


SPSS: Statistical package for social science

Ethics approval and consent to participate

This study was approved by the ethical review board of College of Medicine and Health Sciences, Ambo University. Informed consent to participate in the study was obtained from all participants.

\section{Consent to publication: Not applicable}

Availability of data and material

The datasets during and/or analyzed during the current study are available from the corresponding author on reasonable request.

\section{Funding}

Funding for the research was provided by Ambo university research consultancy and community service director office. Besides financial support, the funding body had no role in the design of the study and collection, analysis, and interpretation of data and in writing the manuscript.

\section{Acknowledgements}

The Authors would like to thank AU for allocating fund to conduct the study. We would also like to express our deepest appreciation to all individuals who supported us during this research work for their indispensable contributions. Last but absolutely not the least, the contribution of the study participants is greatly appreciated.

\section{Authors' contributions}

MM contributed to the conception, design and conduct of the study, analyzed and interpreted the data, and prepared the manuscript.

TB contributed to the design and conduct of the study, analyzed and interpreted the data, and prepared the manuscript. All authors read and approved the final manuscript.

Eshetu E. Chak contributed to the design and conduct of the study, analyzed and interpreted the data, and prepared the manuscript. All authors read and approved the final manuscript

\section{Competing interests}

The authors declare that they have no competing interests.

\section{References}

1. BSC Uzochukwu, OE Onwujekwe, S Eze NE, Obikeze E, Onoka C. Implementing Community Based Health Insurance in Anambra State, Nigeria. 2010.

2. Tabor SR. Community-Based Health Insurance and Social Protection Policy. March 2005:134.

3. Ouimet MJ, Fournier P, Diop I, Haddad S: Solidarity or financial sustainability: an analysis of the values of community-based health insurance subscribers and promoters in Senegal. Can J Public Health 2007, 98(4):341-346.

4. Jacobs B, Bigdeli M, van Pelt M, Ir P, Salze C, Criel B: Bridging community-based health insurance and social protection for health care-a step in the direction of universal coverage? Trop Med Int Health 2008, 13(2):140-143.

5. Ekman B. Community-based health insurance in low-income countries: a systematic review of the evidence. Health Policy Plan. 2004; 19(5):249-270. PubMed $\mid$ Google Scholar

6. Ranson MK, Sinha T, Chatterjee M, Acharya A, Bhavsar A, Morris SS, Mills AJ. Making health insurance work for the poor: learning from the Self-Employed Women's Association's (SEWA) community-based health insurance scheme in India. Soc Sci Med. 2006; 62(3):707-720. PubMed | Google Scholar

7. World Health Organization (WHO). Health financing: a strategy for the African region. Regional Committee for Africa: Fifty-sixth session. 2006. Addis Ababa, Ethiopia. WHO. PubMed $\mid$ Google Scholar

8. Head of Healthcare \& Life Sciences: Africa \& South Africa, The State Of Healthcare In Africa

9. Mills A, Ataguba JE, Akazili J, Borghi J, Garshong B, Makawia S, et al. Equity in financing and use of health care in Ghana, South Africa, and Tanzania: implications for paths to universal coverage. Lancet. 2012;380: $126-33$.

10. Gottret PE, Schieber G. Health financing revisited: a practitioner's guide. Washington: World Bank Publications; 2006

11. Ataguba JE. Reassessing catastrophic health-care payments with a Nigerian case study. Health Econ Policy Law. 2012;7:309-26.

12. Knaul FM, Arreola-Ornelas H, Méndez-Carniado O, Bryson-Cahn C, Barofsky J, Maguire R, et al. Evidence is good for your health system: policy reform to remedy catastrophic and impoverishing health spending in 
Mexico. Lancet. 2006;368:1828-41

13. Bennett S. The role of community-based health insurance within the health care financing system: a framework for analysis. Health Policy Plan. 2004; 19(3):147-58. PubMed | Google Scholar

14. Gamble-Kelley A, Diop F, Makinen M. Approaches for scaling up community-based health financing schemes. Bethesda, MD: Partners for Health Reform Plus Project. 2006. Cambridge. Abt Associates Inc. PubMed | Google Scholar

15. De Allegri M, Sanon M, Bridges J, Sauerborn R. Understanding consumers' preferences and decision to enrol in community-based health insurance in rural West Africa. Health Policy. 2006; 76(1):58-71. PubMed | Google Scholar

16. De Allegri M, Sanon M, Sauerborn R. To enrol or not to enrol: aqualitative investigation of demand for health insurance in rural WestAfrica. Social Sci Med. 2006; 62(6):1520-1527. PubMed | Google Scholar

17. Dong H, De Allegri M, Gnawali D, Souares A, Sauerborn R. Drop-out analysis of community-based health insurance membership at Nouna, Burkina Faso. Health Policy. 2009; 92(2-3):174-179. PubMed | Google Scholar

18. Ataguba JE. Reassessing catastrophic health-care payments with a Nigerian case study. Health Econ Policy Law. 2012;7:309-26.

19. Mbengue, Cheikh. Revitalizing Community-based Health Insurance in Africa to ward Universal Coverage. Health Systems 20/20 Project. Abt Associates Inc. February 28, 2011.

20. Federal Democratic Republic of Ethiopia Ministry of Health, HSDP IV. 2010.

21. Knaul FM, Arreola-Ornelas H, Méndez-Carniado O, Bryson-Cahn C, Barofsky J, Maguire R, et al. Evidence is good for your health system: policy reform to remedy catastrophic and impoverishing health spending in Mexico. Lancet.2006;368:1828-41.

22. Mebratie AD, Sparrow R, Alemu G, Bedi AS. 2013. Community-Based Health Insurance Schemes: A Systematic Review, the 4th Amhara Regional Conference Proceedings. Addis Ababa: Ethiopian Economic Association.

23. Xu K, Evans DB, Kawabata K, Zeramdini R, Klavus J, Murray CJ. Household catastrophic health expenditure: a multicountry analysis. Lancet. 2003;362:111-7.

24. Xu K, Evans DB, Carrin G, Aguilar-Rivera AM, Musgrove P, Evans T. Protecting households from catastrophic health spending. Health Aff. 2007;26:972-83.

25. Limwattananon S, Tangcharoensathien V, Prakongsai P. Catastrophic andpoverty impacts of health payments: results from national household surveys in Thailand. Bull World Health Organ. 2007;85:600-6.

26. Dror DM, Preker AS. Introduction. In: Dror DM, Preker AS, editors. Social reinsurance: a new approach to sustainable community health financing. Washington: World Bank; 2002. p. 627.

27. Shaw RP, Griffin CC. Financing health care in Sub-Saharan Africa through user fees and insurance. Washington: World Bank; 1995.

28. Jütting JP. Do community-based health insurance schemes improve poor people's access to health care? Evidence from rural Senegal. World Dev. 2004;32:273-88

29. Ekman B. Community-based health insurance in low-income countries: a systematic review of the evidence. Health Policy Plan. 2004;19:249-70.

30. Review by USAID, Hailu Zelelew(March 2012) for Health Systems 20/20 project. Health Care Financing Reform in Ethiopia: Improving Quality and Equity

31. Federal Democratic Republic of Ethiopia Ministry of Health, Health Care Financing Team, Policy, Planning and Finance General Directorat, USAID Health Sector Financing Reform Project: Ethiopia's Fourth National Health Accounts, 2007/08 ; Federal Democratic Republic of Ethiopia Ministry of Health, USAID Health Sector Financing Reform Project. 2010.

32. WHO: The world health report: health systems financing: the path to universal coverage. [Internet]. Genev: 2010. Available from: http://www.who.int/whr/ 2010/en/index.html.

33. Federal Democratic Republic of Ethiopia Ministry of Health. Health Sector Transformation Plan , August 2015

34. International Labour Organisation: Extending Social Protection in Health Through Community Based Health Organisations. Evidence and Challenges. Universitas Programme, STEP unit. Geneva: Social Security Policy and Development Branch; 2002

35. Eckhardt, Birger Carl Forsberg, Dorothee Wolf, and Antonio Crespo-Burgos: Feasibility of community-based health insurance in rural tropical Ecuador Martin, 2011.

36. Isaac AO Odeyemi, Community-based health insurance programmes and the national health insurance scheme of Nigeria: challenges to uptake and integration, 2014

37. Adane Kebede, Measho Gebreslassie, Mezgebu Yitayal: Willingness to Pay for Community Based Health Insurance among Households in the Rural Community of Fogera District, North West Ethiopia, 2014.

38. Melaku Haile1*, Shimeles Ololo and Berhane Megersa; Willingness to join community-based health 
insurance among rural households of Debub Bench District, Bench Maji Zone, Southwest Ethiopia , 2014,

39. Dror DM, Hossain SAS, Majumdar A, PérezKoehlmoos TL, John D, Panda PK (2016) What Factors Affect Voluntary Uptake of Community-BasedHealth Insurance Schemes in Low- and Middle-Income Countries? A Systematic Review and Meta- Analysis. PLoS ONE 11(8): e0160479. doi:10.1371/ journal.pone.0160479

40. Asfaw A, Von Braun J. Can community health insurance schemes shield the poor against the downside health effects of economic reforms? The case of rural Ethiopia. Health Policy. 2004;70:97-108.

41. Okello F, Feeley F. Socioeconomic characteristics of enrollees in community health insurance schemes in Africa. Washington: USAID/Commercial Market Strategies Project; 2004.

42. Panda P, Chakraborty A, Dror DM, Bedi A. Enrolment in community-based health insurance schemes in rural Bihar and Uttar Pradesh, India. Health Policy and Planning. 2013; 29(8):960-974. doi: 10.1093/ heapol/czt077 PMID: 24162838

43. Kuwawenaruwa A, Macha J, Borghi J. Willingness to pay for voluntary health insurance in Tanzania. East African Medical Journal. 2011; 88(2):54-64. PMID: 24968592

44. Ranson MK. Reduction of catastrophic health care expenditures by a community-based health insurance scheme in Gujarat, India: currentexperiences and challenges. Bull World Health Organ. 2002;80:613-21.

45. Zhang L, Wang H, Wang L, Hsiao W. Social capital and farmer's willingness-to join a newly established community-based health insurance in rural China. Health Policy. 2006;76:233-42

46. Aggarwal A. Achieving equity in health through community-based health insurance: India's experience with a large CBHI Programme. Kobe: Discussion Paper Series- DP2010-31, RIEB, Kobe University; 2010 Nov 10.

47. De Allegri M, Sanon M, Bridges J, Sauerborn R. Understanding consumers' preferences and decision to enrol in community-based health insurance in rural west Africa. Health Policy. 2006b; 76(1):58-71. 